\title{
Experimental and Finite Element Method of Castellated Steel Beam with and without Hexagonal web Opening
}

\author{
Premkumar R, Ramesh Babu Chokkalingam, M Shanmugasundaram
}

\begin{abstract}
Castellated beams are made from the conventional I section by the process named as Castellation Process. As of late, broad examination on these castellated steel beams has been directed, including various shapes in web openings. The primary objective of these examination works was to assess and dissect its ideal opening sizes and shapes arrangement. For the most part castellated beam are given hexagonal, round and square formed openings. The finite element investigation is most favored technique for comprehension the flexural strength of castellated beams. In this examination, experimental and numerical displaying approach is utilized for deciding spacing between openings on hexagonal castellated beam. ANSYS software was utilized for the investigation. Opening edge $60^{\circ}$ with various opening dispersing $0.15 d$ and $0.25 d$ have beam utilized. Investigation was selected steel beam with and without web openings of ISMB 150 and solid ISMB200 section. Results demonstrated that the castellated bar with hexagonal opening indicated more load carrying capacity and less significant deflection contrasted with solid beam.
\end{abstract}

Keywords : ANSYS, Castellated beam, Deflection, Finite Element Analysis.

\section{INTRODUCTION}

$W_{\text {eb opening of steel beams with primary section }}$ characteristics are like to one another. The most critical parameter in studying the basic execution of the opening portions is the essential opening length. While the opening significance controls the shear and the minute resistance of a punctured area, it is the fundamental opening length of the web opening that controls the all auxiliary conduct of steel segment. Furthermore all sorts of failure modes are relying on the opening of web, loading and bolster conditions [1]. vierendeel mechanism is one of the failure mechanism of six potential failure mode in web opening steel beam. These mechanisms is reason yielding or buckling of the web in compression or shear and break of the welded joint are nearby disappointment normal to castellated beam, so for web with enormous opening lengths under high shear to moment proportion. vierendeel system is powerless to happen [2]. On account of this component as well, the four

Revised Manuscript Received on December 5, 2019

* Correspondence Author

Premkumar R*, School of Environmental and Construction Technology, Department of Civil Engineering, Kalasalingam Academy of Research and Education, Krishnan Koil, Tamil Nadu, India.Email: prem.ce@gmail.com

Ramesh Babu Chokkalingam, School of Environmental and Construction Technology, Department of Civil Engineering, Kalasalingam Academy of Research and Education, Krishnan Koil, Tamil Nadu, India.

M Shanmugasundaram, School of Mechanical and Building Sciences, Vellore Institute of Technology, Chennai, Tamil Nadu, India. plastic hinges at the upper and the base of the T segment will deform [3]. The strategy for castellation is basic without utilizing extra material so the expense of development is decreased. A great deal of study has been done in upgrading the elements of punctured web steel beam with various shapes like hexagonal, octagonal, square, roundabout, and so on opening in regard of flexural action[4],[5]. Next to no work has been done to maintain a strategic distance from disappointment of castellated bars, it has been recommended to give stiffener legitimate measurements and locations.

Numerous analysts inferred that, beam depth of the section is expanding; deflection of beam is diminishing for every range and for every beams. This shows up as far as possible, castellated bars have more burden conveying limit than its parent segments of beam [6]. The real method of disappointment is lateral torsional buckling and that is decreased in solid beam than castellated beams [7]. It is presume that castellated beams are very much acknowledged for industrial structures, control plant and multistoried structures, where by and large loads are less and ranges are more with its economy and fulfilling usefulness criteria and also plainly it ought to be suggested in higher seismic zone [8]. In addition compare the all type shape of web opening steel beam with hexagonal opening indicated more quality on the grounds that during its manufacture procedure there is no loss of material, yet for the creation of round opening there is loss of materials[9]. The significant disservice of castellated beam is the presentation of an opening in the web of the beam changes the pressure circulation inside the part and furthermore impacts its collapse behavior. These openings decline the stiffness of the beams resulting in larger deflection.

\section{METHODOLOGY}

In this examination was directed numerically and experimentally utilizing the limited component investigation. Finite element analysis was carryout with the ANSYS software and also compare with experimental tests result were using to legalize the model. In this study an ISMB150 was selected as parent steel beam. The first steel beam was adjusted into a castellated steel beam with hexagonal molded openings for different distance. In this way the overall depth of castellated beams after aperture depth up $225 \mathrm{~mm}$. The adjustment can be showed in figure 1 .

Published By: 
Experimental and Finite Element Method of Castellated Steel Beam with and without Hexagonal web opening
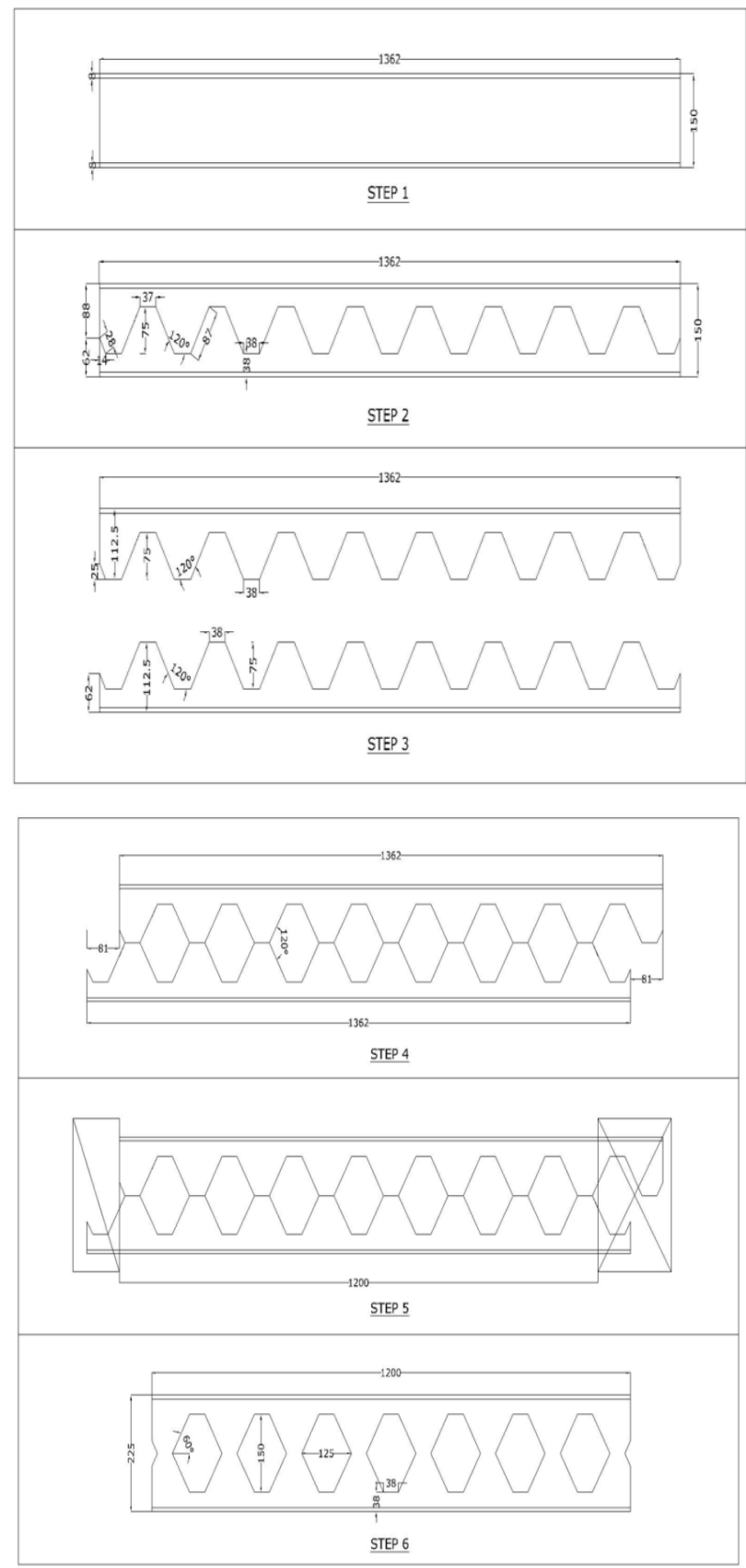

Fig. 1. Modeling of Castellated beam

An all out four models diverse steel beam was considered. The adjustment of castellated steel beam separated keep on two types of specimens they were MB1, MB2. MB1 and MB2 was developed as castellated into different opening space $0.25 \mathrm{~d}$ and $0.15 \mathrm{~d}$ from research investigation [5], [6], [7], [9]. The variety of opening edge $60 \mathrm{o}$ was tried to get the yielding load and the deflection at the centre and under the loading focuses [9]. MB3 and MB4 are selected the solid standard steel beam section ISMB150 and ISMB 200 respectively. In this present work all the material properties of elastic modulus 200MPa and passion ratio 0.3 which was used for steel beam. The section properties examples are appeared table I and table II. In the exploratory test, they chose steel beams were analyzed utilizing a two point stacking framework with simply support conditions for the two ends.

Table- I: Section Properties of Solid Beam

\begin{tabular}{|c|c|c|}
\hline $\begin{array}{c}\text { Section } \\
\text { Properties }\end{array}$ & $\begin{array}{c}\text { MB3 } \\
\text { (ISMB150) }\end{array}$ & $\begin{array}{c}\text { MB4 } \\
\text { (ISMB200) }\end{array}$ \\
\hline $\begin{array}{c}\text { Weight per meter } \\
(\mathrm{kg})\end{array}$ & 14.9 & 25.4 \\
\hline $\begin{array}{c}\text { Sectional area } \\
\left(\mathrm{cm}^{2}\right)\end{array}$ & 16 & 32.30 \\
\hline $\begin{array}{c}\text { Depth of Section } \\
(\mathrm{mm})\end{array}$ & 150 & 100 \\
\hline $\begin{array}{c}\text { Width of Flange } \\
(\mathrm{mm})\end{array}$ & 80 & 10.8 \\
\hline $\begin{array}{c}\text { Thickness of } \\
\text { Flange (mm) }\end{array}$ & 7.6 & 5.7 \\
\hline $\begin{array}{c}\text { Thickness of } \\
\text { Web (mm) }\end{array}$ & 4.8 & 200 \\
\hline
\end{tabular}

Table- II: Section Properties of Castellated Beam

\begin{tabular}{|c|c|c|}
\hline $\begin{array}{c}\text { Castellated } \\
\text { Beam Section } \\
\text { Properties }\end{array}$ & MB1 & MB2 \\
\hline $\begin{array}{c}\text { Parent Steel } \\
\text { Beam }\end{array}$ & ISMB150 & ISMB150 \\
\hline $\begin{array}{c}\text { Final depth of } \\
\text { Section (mm) }\end{array}$ & 230 & 230 \\
\hline Opening shape & hexagonal & hexagonal \\
\hline $\begin{array}{c}\text { Spacing of } \\
\text { Opening (mm) }\end{array}$ & 20 & 38 \\
\hline Cutting angle & $60^{\circ}$ & $60^{\circ}$ \\
\hline
\end{tabular}

\section{EXPERIMENTAL WORK}

When all is said in done, the lab test was carryout utilizing hinge and roller support system beam oppressed with two point load frame works. The experimental test specimens were two web opening and with two solid beams. The clear supporting length of the beam was $1000 \mathrm{~mm}$. figure 2 to 4 demonstrates preparation and lab testing arrangement.

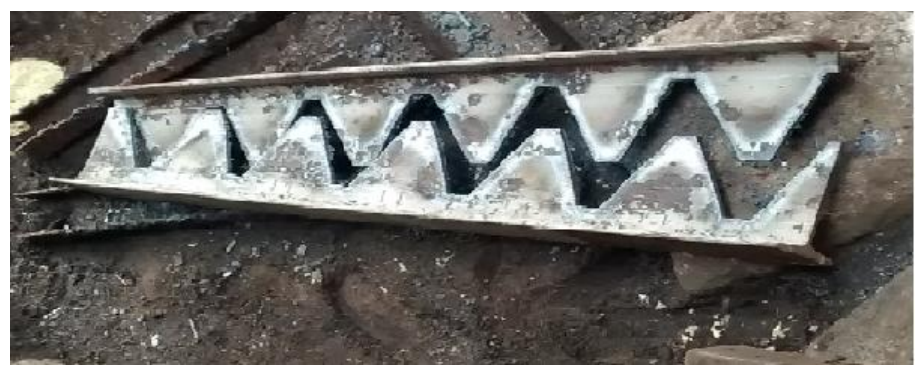

Fig. 2. Cutting of Castellated beam

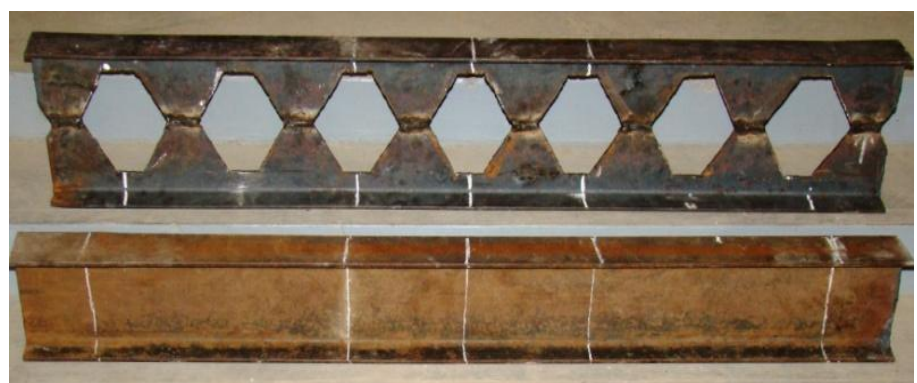

Fig. 3. Fabricated of Castellated beam

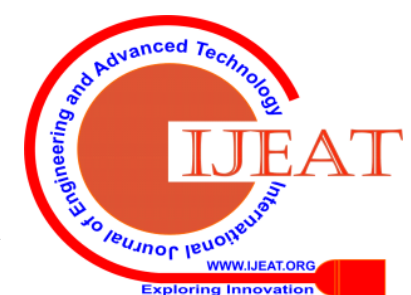




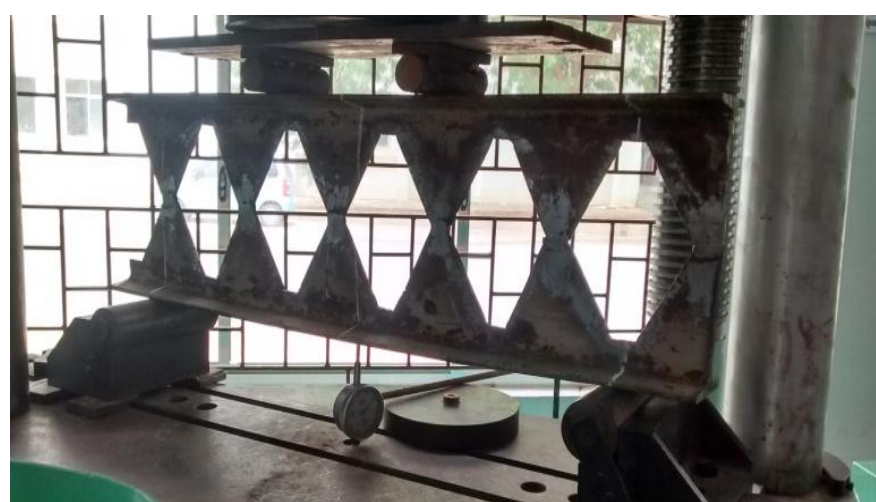

Fig. 4. Two point Load set up

\section{FINITE ELEMENT ANALYSIS}

The numerical model is created to mimic the behavior of castellated steel beam having I- section as shown in figure 5 to 8. Displaying and assessing was finished utilizing ANSYS. Utilizing material properties Young ${ }^{\text {ee }} \mathrm{s}$ modulus $\mathrm{E}=$ $2.1 \times 10^{5} \mathrm{MPa}$ and Poisson ${ }^{e e} \mathrm{~s}$ proportion $v=0.3$. Static investigation was performed to decide the deflection of the solid beam and castellated steel beam having hexagonal different spacing openings.

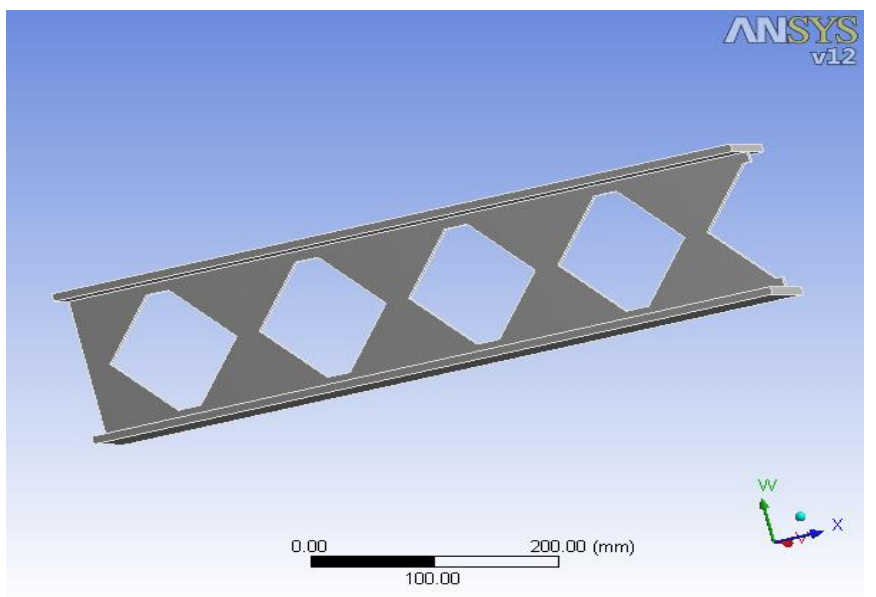

Fig. 5. Finite Element Modeling for Castellated Beam

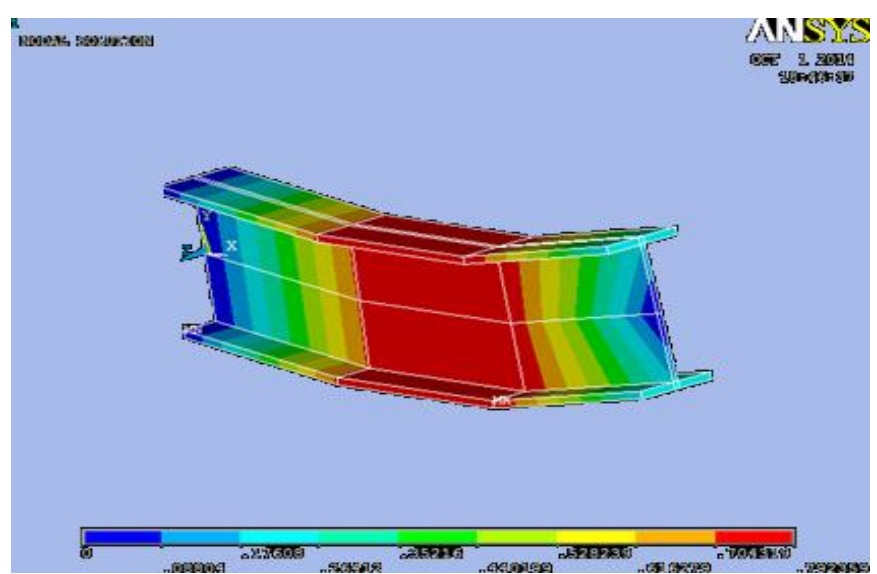

Fig. 6. Deformation mode of Normal Beam

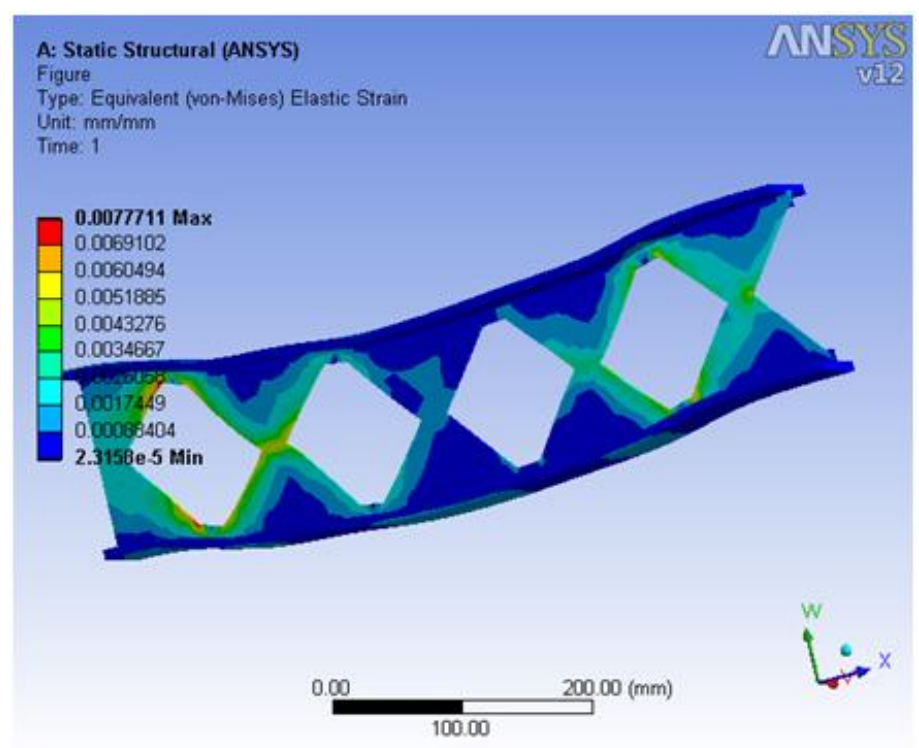

Fig. 7. Von - Mises Analysis of Castellated Beam

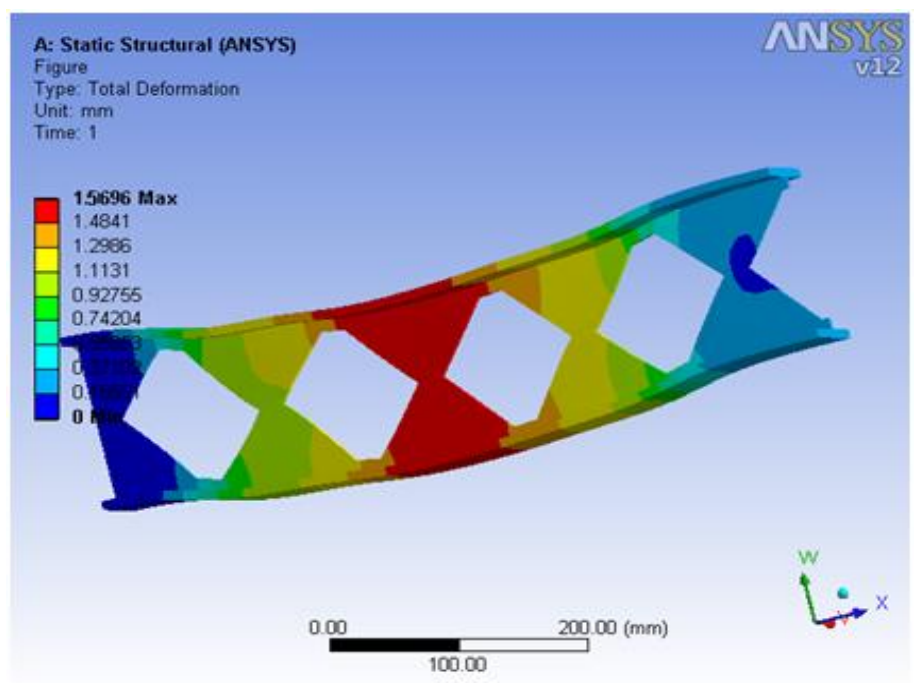

Fig. 8. Deformation mode of Castellated Beam

\section{RESULT AND DISCUSSION}

From the figure 9 shows experimental and numerical investigation obviously steel beam with less hexagonal less space opening MB1 show more load carrying capacity and smaller deflection when contrasted with MB 3 and MB4. Von-Mises stresses were created for steel beam with hexagonal opening MB1 and MB2, it was seen that the pressure focus is increasingly close to the opening prompting shear disappointment. Investigation of test results was performed at the CB1 models for hexagonal hole cutting angle $60^{\circ}$. As indicated by table III, it tends to be seen that the research testing results has around similar outcomes with FEM examination. Deflection of steel beam CB1 reached a deflection 1.58 at $120 \mathrm{kN}$, MB2 reached the deflection of $1.72 \mathrm{~mm}$. Meanwhile for MB3 and MB4 reached was 1.71 and 1.64 respectively at same load carrying capacity. But MB1 deflection is reduced 8 and $4 \%$ compare $\mathrm{MB} 3$ and

Published By:

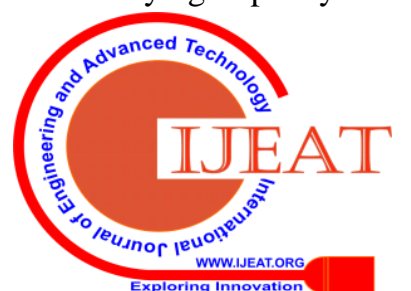


MB4.

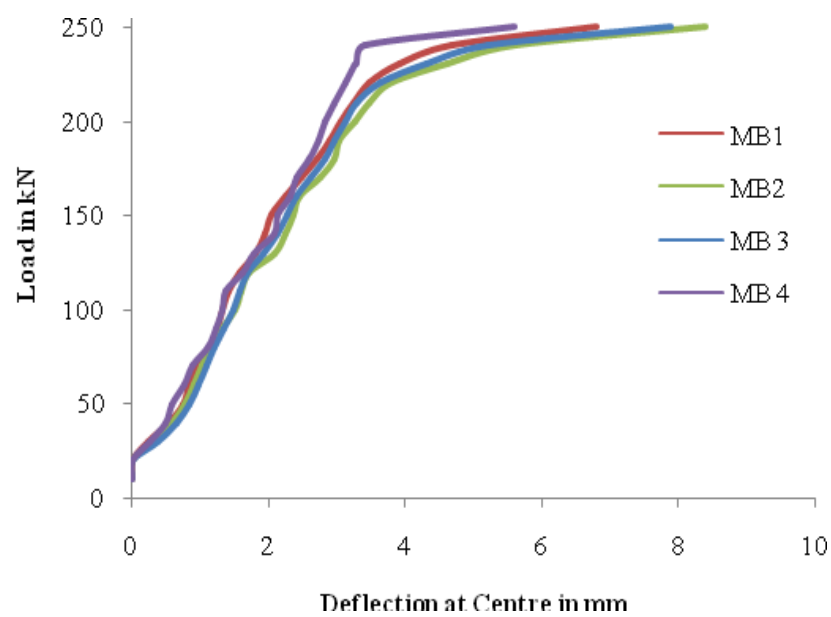

Fig. 9. Load vs Deflection of Beam

Table- III: Deflection value at corresponding load at $120 \mathrm{kN}$

\begin{tabular}{|c|c|}
\hline Section & Deflection at 120kN \\
\hline MB 1 & $1.58 \mathrm{~mm}$ \\
\hline MB 2 & $1.72 \mathrm{~mm}$ \\
\hline MB 3 & $1.71 \mathrm{~mm}$ \\
\hline MB 4 & $1.64 \mathrm{~mm}$ \\
\hline
\end{tabular}

\section{CONCLUSION}

- In view of the outcomes, increment the profundity of the steel beam there is critical decrease in deflection contrasted with unique and same profundity of the beam.

- The variety in results for theoretical and utilizing programming ANSYS is under 5\%, this is because of dimensional linearity, material properties and limited impact of three dimensional demonstrating in ANSYS.

- At the point when compared with MB1 and MB2 the deflection was diminished due to expanded height of the beam.

- The outcomes additionally affirm that the flexural strength of castellated beams decline as the profundity of opening increments.

- Castellated steel beam carries on agreeably with respect to functionality necessities of web opening profundity $0.25 \mathrm{~d}$. Castellated beam have gaps in its web, which lead to shear failure impacts in the beams

\section{REFERENCES}

1. Richard Frans, Herman Parung, Desi Sandy and Surianti Tonapa, "Numerical Modelling of Hexagonal Castellated Beam under Monotonic Loading", Procedia Engineering., vol 171, pp. 781 - 788, 2017.

2. T.C.H. Liu, K.F. Chung, "Steel beams with large web openings of various shapes and sizes: finite element investigation", Journal of Constructional Steel Research, vol. 59 (2003), pp. 1159-1176, 2003, Available from: https://doi:10.1016/S0143-974X (03)00030-0.
3. M.R.Wakchaure, A.V. Sagade, "Finite Element Analysis of Castellated Steel Beam", International Journal of Engineering and Innovative Technology, vol. 2, pp. 365-372, 2012

4. Resmi Mohan, Preetha Prabhakaran," Finite Element Analysis to Compare the Deflection of Steel Beam with and without Web Openings", Journal of Mechanical and Civil Engineering (IOSR-JMCE), e-ISSN: 2278-1684,p-ISSN: 2320-334X, PP 07-11, 2016.

5. Gopika S Nair, Dr.P.R. Sreemahadevan Pillai, "Review on Characteristics of Castellated Beam", International Research Journal of Engineering and Technology, vol 5(4), 2018.

6. S Tudjono, Sunarto and A L Han, "Analysis of castellated steel beam with oval openings", IOP Conf. Series: Materials Science and Engineering, 271 (2017) 012104, Available from: https://doi:10.1088/1757-899X/271/1/012104.

7. Morkhade .G, Gupta.M, "Analysis of Steel I-Beams with Rectangular Web Openings: Experimental and Finite Element Investigation", Engineering Structures and Technologies, vol.7(1), pp. 13-23, 2015, Available from: https://doi:10.3846/2029882X.2015.1085332

8. Pattamad, P.; Thaksin," Finite element investigation on deflection of cellular beams with various configurations", International Journal of Steel Structures, vol. 13(3), pp.487-494, 2013, Available from: http://dx.doi.org/10.1007/s13296-013-3008-z.

9. Listiyono Budi, Sukamta, Windu Partono, "Optimization Analysis of Size and Distance of Hexagonal Hole in Castellated Steel Beams", Procedia Engineering, 171(2017), 1092-1099, 2017, htts://doi: 10.1016/j.proeng.2017.01.465

\section{AUTHORS PROFILE}

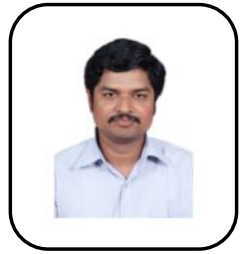

R.Premkumar had completed B.E degree in Civil Engineering and M.E degree in Structural Engineering from Anna University Chennai, Tamil Nadu in 2008 and 2012 respectively. He is currently working as Assistant Professor in the department of Civil Engineering at Kalasalingam Academy of Research and Education. He has 2 year of industrial experience and 7 years experience in academics and consultancy. His current research interests are Geopolymer Concrete and Earthquake resistance structures.

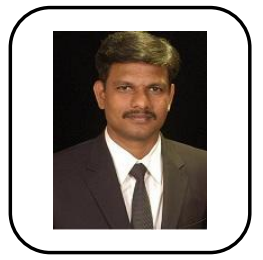

Ramesh Babu Chokkalingam completed his Ph.D from IIT Chennai. He has more than ten years of experience in teaching and research. His area of research includes pervious concrete, geopolymer concrete, and high volume flyash concrete.

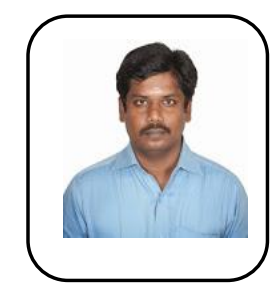

Dr M.Shanmugasundaram: He had completed his B.E degree in Civil Engineering from RCET Madurai, M.E in Structural Engineering, TCE Madurai. He completed his Ph.D in 2014 under the esteemed guidance of Dr. K.Sudalaimani, Professor, TCE, Madurai. He has 30+ international research publications to his credits. He had filed three patents. He has 3 years of industrial experience and 10 years of teaching experience. His recent research interests include sustainable materials and polymer concrete. 